crossinfection of babies was a possibility in Sweden (Larsson et al., 1978), but this could not be so in these two cases as the illnesses were caused by different serotypes, although the interval between them was only a few weeks.

We have found 10 cases reported in which the pregnant woman was treated (Hood, 1961; Sepp and Roy, 1963; LeGouguec et al., 1971) and the diagnosis was proved by blood culture. A wide variety of antibiotics was used-such as penicillin, tetracycline, spiramycin, sulphonamide, chloramphenicol, and streptomycin, alone or in various combinations. These 10 cases resulted in 7 healthy babies, 2 infected babies, and one abortion. Our Case 2 appears to be the first to be described in Britain. Kanamycin and ampicillin in combination proved very effective in the New Zealand outbreak (Becroft et al., 1971) and gentamicin and ampicillin in combination were successful in our patients.

We thank the Epidemiological Research Laboratory for data on the incidence of the disease, Mrs A. J. Macara of the Standards Laboratory of the Central Public Health Laboratory for typing the strains, the Nicholas Research Institute for measuring serum gentamicin levels, Dr R. G. M. Letcher for the histological opinions, and Mrs B. Miles for clerical assistance.

\section{References}

Barber, M., and Okubadejo, O. A. (1965). Maternal and neonatal listeriosis. Report of case and brief review of literature of listeriosis in man. British Medical Journal, 2, 735-738.

Barrow, G. T., and Pugh, R. J. (1958). Listeria (Erysipelothrix) monocytogenes meningitis in the newborn. Journal of Pathology and Bacteriology, 75, 9-15.

Beck, A., O'Brien, P. K., and MacKenzie, V. F. (1966). Case of stillbirth due to infection with Listeria monocytogenes. Journal of Clinical Pathology, 19, 567-569.

Becroft, D. M. O., Farmer, K., Seddon, R. J., Sowden, R.,
Stewart, J. H., Vines, A., and Wattie, D. A. (1971). Epidemic listeriosis in the newborn. British Medical Journal, 3, 747-751.

Coleman, P. N. (1965). Letter: Neonatal listeriosis. British Medical Journal, 2, 878.

Edmunds, P. N., Nicholson, D. N., and Douglas, D. M. (1957). Two cases of listerial meningitis in infants. British Medical Journal, 2, 188-191.

Harding, J. W., and Brunton, G. B. (1962). Listeria monocytogenes meningitis in neonates. Lancet, 2, 484-486.

Hood, M. (1961). Listeriosis as an infection of pregnancy manifested in the newborn. Pediatrics, 27, 390-396.

Jellard, C. H., and Churcher, G. M. (1965). Letter: Neonatal listeriosis. British Medical Journal, 2, 878.

Kite, P. (1975). Obstetric and neonatal listeriosis-case histories and placental survey. In Problems of Listeriosis. Proceedings of the Sixth International Symposium, Nottingham 1974, pp. 193-196. Edited by M. Woodbine. Leicester University Press: Leicester.

Larsson, S., Cederberg, A., Ivarsson, S., Svanberg, L., and Cronberg, S. (1978). Listeria monocytogenes causing hospital-acquired enterocolitis and meningitis in new born infants. British Medical Journal, 2, 473-474.

Le Gouguec, C., Toulouse, R., Dubois, J., Toussaint, A., and Kerisit, J. (1971). La listeriose chez la femme enceinte. Presse médicale, 79, 870.

Moore, S., and Whitmore, D. N. (1960). Case of listeria meningitis. British Medical Journal, 2, 1572-1573.

Robertson, M. H. (1977). Listeriosis. Postgraduate Medical Journal, 53, 618-622.

Scott, J. M., and Henderson, A. (1968). A case of listeriosis of the newborn. Journal of Medical Microbiology, 1, 97-104.

Seeliger, H. P. R., Emmerling, R., and Emmerling, H. (1969). Listeriosis in Germany. German Medical Monthly, 14, 157-163.

Sepp, A. H., and Roy, T. E. (1963). Listeria monocytogenes infections in metropolitan Toronto. Canadian Medical Association Journal, 88, 549-561.

Turner, G. C., Dawson, I. M. P., and Pryce-Jones, E. (1958). Fatal Listeria monocytogenes meningitis in a child aged 3 months. Journal of Clinical Pathology, 11, 266-269.

Wright, H. A., and Macgregor, A. R. (1939). A case of meningitis due to bacterium monocytogenes. Journal of Pathology and Bacteriology, 48, 470-472.

Correspondence to Dr M. H. Robertson, St Margaret's Hospital, Department of Pathology, Epping, Essex CM16 6TN.

\title{
Water intoxication by the oral route in an infant
}

\section{AMOS ETZIONI, ABRAHAM BENDERLEY, AND YOSEF LEVI}

\author{
Department of Paediatrics A, Aba Khoushy School of Medicine, Haifa
}

SUMMARY Symptomatic water intoxication is common when hypo-osmolar fluids are given therapeutically, usually intravenously, but it is rare after drinking voluntarily (Wynn and Rob, 1954). We report a case of water intoxication caused by voluntary drinking in an infant.

\section{Case report}

A 10-month-old girl was admitted to hospital because of generalised convulsions which had begun an hour earlier. The child was born to a healthy mother after an uneventful pregnancy and normal delivery. Her birthweight was $3200 \mathrm{~g}$ and development until 
admission had been normal. Family history was negative and no history of excessive water requirement was noted.

On the evening before admission she developed a fever $\left(38^{\circ} \mathrm{C}\right)$ and slight diarrhoea. The parents were advised by a doctor 'to give her a lot to drink'. The child was restless and between 01.30 and 04.00 hours she drank about 1 litre of water, without the addition of salt or sugar. Soon after 04.00 hours convulsions began. The child was brought to the emergency room. She received diazepam $2 \mathrm{mg}$ IV, but after 10 minutes the convulsions recurred.

Examination on admission showed a well nourished girl weighing $9600 \mathrm{~g}$. The temperature was $38^{\circ} \mathrm{C}$, blood pressure $110 / 70 \mathrm{mmHg}$, pulse $100 / \mathrm{min}$. She was lethargic and responded only to painful stimuli. Periorbital oedema was noticed.

CSF was clear with no cells, protein $20 \mathrm{mg} / 100 \mathrm{ml}$ $(0.2 \mathrm{~g} / \mathrm{l})$, glucose $120 \mathrm{mg} / 100 \mathrm{ml}(6.66 \mathrm{mmol} / \mathrm{l})$, bacterial culture-negative. Serum sugar $315 \mathrm{mg} /$ $100 \mathrm{ml}(17 \cdot 5 \mathrm{mmol} / \mathrm{l}), \mathrm{Ca} 9 \mathrm{mg} / 100 \mathrm{ml}(2 \cdot 25 \mathrm{mmol} / \mathrm{l})$, P $6 \mathrm{mg} / 100 \mathrm{ml}(1.9 \mathrm{mmol} / \mathrm{l})$, urea $25 \mathrm{mg} / 100 \mathrm{ml}$ (4.15 mmol/l), K $4 \cdot 3 \mathrm{mEq} / \mathrm{l}, \mathrm{Na} 118 \mathrm{mEq} / \mathrm{l}$ (on repeated examination), $\mathrm{Cl} 82 \mathrm{mEq} / \mathrm{l}$, bicarbonate $25 \mathrm{mEq} / \mathrm{l}$. Urine electrolytes $\mathrm{Na} 25 \mathrm{mEq} / \mathrm{l}, \mathrm{K} 14$ $\mathrm{mEq} / \mathrm{l}$. Blood osmolality $255 \mathrm{mmol}$ (normal 280 mmol). Urine osmolality $87 \mathrm{mmol}$. EEG showed generalised slowing.

She was treated with hypertonic saline ( $2 \%) 300 \mathrm{ml}$ IV and after some hours she became alert and began to eat normally; the convulsions did not recur. Serum $\mathrm{Na}, 8$ hours after admission was $138 \mathrm{mmol} / \mathrm{l}$ and remained normal thereafter. Her weight the next day was $9050 \mathrm{~g}$; she had therefore lost $550 \mathrm{~g}$. The blood glucose rapidly returned to normal with a 2 hour-postprandial value of $85 \mathrm{mg} / 100 \mathrm{ml}(4 \cdot 7$ $\mathrm{mmol} / \mathrm{l})$. EEG returned to normal after a week. She was discharged and at follow-up 6 months later was doing well.

The history, laboratory data, weight loss, and clinical course left no doubt that the diagnosis was one of water intoxication.

\section{Discussion}

Involuntary water intoxication can be caused by IV administration of fluids which contain small amounts of saline. It may also follow gastric lavages or enemas, and be present in patients suffering from compulsive water drinking. Voluntary water intoxication in children is rare, and only 5 similar cases have been reported (Dugan and Holliday, 1967; Nickman et al., 1968; Pickering and Hugan, 1971; Crumpacker and Kriel, 1973).

The two principal variables in maximum water tolerance (Pickering and Hugan, 1971) are the ability of the kidney to dilute, and the maximum renal tubular excretion capacity of water. The kidneys in a 3-month infant are mature as regards their ability to excrete water (Fisher et al., 1963) and our 10-monthold patient could therefore be expected to excrete water as satisfactorily as an adult. When a water load is given $(20 \mathrm{ml} / \mathrm{kg})$ the expected response would be excretion of at least $75 \%$ of the water in 4 hours (De Wardener, 1973), but if the load were more than five times greater, as in our case $(110 \mathrm{ml} / \mathrm{kg})$, it is reasonable to expect that such a load would not be excreted and that water intoxication would develop.

One hypothesis for the mechanism of this syndrome is that the infant has an inappropriate secretion of antidiuretic hormone or a delayed switch-off of ADH release. This would lead to retained fluid or a delayed excretion of the water load. As most infants are 'sick' before they are given large, 'voluntary' loads of fluid, one might suggest such a mechanism. Measurements of ADH secretion have not been made in such infants, but the low osmolality of the urine in our patient is against such an hypothesis because, if secretion of ADH is inappropriate, urine osmolality must be high. The hyperglycaemia in our patient may have been caused by the convulsions (Rutter and Smales, 1977).

Symptoms of hyponatraemia usually begin when serum Na $<120 \mathrm{mEq} / \mathrm{l}$ (Wynn and Rob, 1954), but they will begin sooner if the hyponatraemia develops rapidly, as in our child who probably became hyponatraemic in less than 4 hours.

When treating with hypertonic saline, it is not known how rapidly levels of plasma $\mathrm{Na}$ can safely be raised in patients with acute hyponatraemia, nor how long it takes for acute hyponatraemia to cause permanent brain damage. Apart from hypertonic saline (usually $3 \%$ ) and water restriction, no other form of treatment has proved to be effective (Crumpacker and Kriel, 1973).

This case once more emphasises the need for clarity when prescribing; the laconic order 'to give a lot to drink' allows room for much ambiguity. The physician should be specific with regard to the kind of fluid to be given, its amount, and frequency of administration.

\section{References}

Crumpacker, R. W., and Kriel, R. L. (1973). Voluntary water intoxication in normal infants. Neurology, 23, 12511255.

De Wardener, H. E. (1973). The Kidney, fourth edition, p. 61. Churchill-Livingstone: Edinburgh.

Dugan, S., and Holliday, M. A. (1967). Water intoxication in two infants following the voluntary ingestion of excessive fluids. Pediatrics, 39, 418-419.

Fisher, D. A., Pyle, H. R., Jr, Porter, J. C., Beard, A. G. and Panos, T. C. (1963). Control of water balance in the 
newborn. American Journal of Diseases of Children, 106, 137-146.

Nickman, S. L., Buckler, J. M., and Weiner, C. B. (1968). Further experiences with water intoxication. Pediatrics, 41, 149-151.

Pickering, C. K., and Hugan, G. R. (1971). Voluntary water intoxication in a normal child. Journal of Pediatrics, 78, 316-318.

Rutter, N., and Smales, C. R. (1977). Role of routine investi- gations in children presenting with their first febrile convulsions. Archives of Disease in Childhood, 52, 188-191.

Wynn, V., and Rob, C. G. (1954). Water intoxication: differential diagnosis of the hypotonic syndromes. Lancet, $1,587-594$.

Correspondence to Dr A. Etzioni, Department of Paediatrics A, Rambam University Hospital, Aba Khoushy School of Medicine, Rambam Medical Center, Haifa, Israel.

\title{
Copper deficiency in a low birthweight infant
}

\author{
P. YUEN, H. J. LIN, AND J. H. HUTCHISON \\ University Departments of Paediatrics and Pathology, Queen Mary Hospital, Hong Kong
}

SUMMARY Copper deficiency is reported in an infant of very low birthweight. It was characterised by extensive bone changes, severe neutropenia, and hypocupraemia. These manifestations could have been missed but for an intercurrent pneumonia which led to an $x$-ray of the chest.

Low birthweight infants go into negative nitrogen balance from birth and there may also be substantial losses of trace elements (Shaw, 1973). Absorption of nutrients may also be poor. It is surprising, therefore, that there have been so few reports of copper deficiency in low birthweight infants (Al-Rashid and Spangler, 1971; Griscom et al., 1971; Ashkenazi et al., 1973; Sann et al., 1978) and it is possible that some cases go unrecognised.

\section{Case report}

A Chinese baby, son of a 28-year unmarried hostess at a dance hall, was born spontaneously in the hospital casualty department at 28 weeks' gestation on 24 August 1977. Birthweight $970 \mathrm{~g}$; length $39 \mathrm{~cm}$; head circumference $26 \mathrm{~cm}$. The clinical and radiological features of idiopathic RDS rapidly developed. The infant was nursed in an incubator in $60 \% \mathrm{O}_{2}$, an umbilical artery was catheterised for blood-gas studies, and IV $10 \%$ dextrose was given at a rate of $3 \mathrm{ml} /$ hour. Apnoeic attacks necessitated the use of CPAP on 25 August and IV aminophylline was given $1.5 \mathrm{mg}$ six-hourly. $\mathrm{PaO}_{2}$ varied between 47 and 115 mmHg $(6 \cdot 2$ and $15 \cdot 3 \mathrm{kPa})$. Metabolic acidosis was corrected with sodium bicarbonate. Parenteral feeding with Aminofusin, dextrose, and Intralipid was started on 26 August. CPAP was stopped on 30 August, and the ambient $\mathrm{O}_{2}$ concentration gradually reduced. An attempt at nasogastric feeding on 31 August produced blood from the gastric aspirate and $\mathrm{Hb}$ fell to $10 \mathrm{~g} / \mathrm{dl}$, and then rose to 15 $\mathrm{g} / \mathrm{dl}$ after a transfusion of $25 \mathrm{ml}$ fresh blood. Parenteral feeding was discontinued on 20 September when the infant's full caloric requirements were being given in the form of Nan (Nestlé) by nasogastric tube. $\mathrm{Hb}$ was $11.5 \mathrm{~g} / \mathrm{dl}$. On 1 October proprietary ferrous sulphate and multivitamin preparations were started orally. However, on 4 October $\mathrm{Hb}$ was $7.6 \mathrm{~g} / \mathrm{dl}$; WBC $45.1 \times 10^{9} / 1$; neutrophils $31 \%$; lymphocytes $69 \%$; platelets $645 \times$ $10^{9} / 1$; reticulocytes $4 \cdot 8 \%$. Films showed 12 nucleated $\mathrm{RBC} / 100$ WBC. On the suspicion of vitamin $\mathrm{E}$ deficiency (Willoughby, 1977) IM tocopherol $100 \mathrm{mg}$ daily was given for 4 days. Unfortunately, the infant developed bronchopneumonia (treated with IV gentamicin and ampicillin) and on 17 October $\mathrm{Hb}$ was $6.3 \mathrm{~g} / \mathrm{dl}$; reticulocytes $8.7 \%$. A further 4-day course of tocopherol was given and on 10 November $\mathrm{Hb}$ was $11.3 \mathrm{~g} / \mathrm{dl}$; reticulocytes $2 \cdot 6 \%$. The infant was discharged home on 22 November on Nan $75 \mathrm{ml}$ three-hourly $\times 8$, plus iron and vitamin supplements. Weight $2 \cdot 33 \mathrm{~kg}$; head circumference $32.5 \mathrm{~cm}$.

The baby was readmitted on 13 December extremely ill and convulsing with bronchopneumonia. Weight $3.0 \mathrm{~kg}$. Respirations $60 / \mathrm{min}$. Blood $\mathrm{pH}$ $7.03 ; \mathrm{PaO}_{2} 73 \mathrm{mmHg}(9 \cdot 7 \mathrm{kPa}) ; \mathrm{PaCO}_{2} 94 \mathrm{mmHg}$ $(12.5 \mathrm{kPa})$; base excess-7.5 mmol/1. Serum Na 132 $\mathrm{mmol} / \mathrm{l} ; \mathrm{K} 5 \cdot 8 \mathrm{mmol} / 1 ; \mathrm{Ca} 2 \cdot 4 \mathrm{mmol} / 1(9.6 \mathrm{mg} /$ $100 \mathrm{ml}) ; \mathrm{P} 2.38 \mathrm{mmol} / 1(7.4 \mathrm{mg} / 100 \mathrm{ml}) ; \mathrm{Mg} 1 \cdot 0$ $\mathrm{mmol} / \mathrm{l}(2 \cdot 4 \mathrm{mg} / 100 \mathrm{ml})$. Hb $10 \cdot 2 \mathrm{~g} / \mathrm{dl}$; WBC $20 \cdot 3$ $\times 10^{9} / 1$; neutrophils $26 \%$; lymphocytes $67 \%$; monocytes $7 \%$; reticulocytes $4 \cdot 6 \%$. CSF normal. There was a good response to cephradine given IV combined with nursing in $40 \% \mathrm{O}_{2}$. However, a repeat chest $x$-ray on 21 December showed widening of the anterior rib ends, subperiosteal reaction, and fractures of the right 6 th, 7 th, and 8th ribs and of the left 5th, 6th, 7th, and 8th ribs.

A skeletal survey showed diaphyseal subperiosteal 